\title{
Anti-KJ: A New Antibody Associated with the Syndrome of Polymyositis and Interstitial Lung Disease
}

Ira N. Targoff, Frank C. Arnett, Louis Berman, Charles O'Brien, and Morris Reichlin

Department of Medicine, Combined Immunology Section, Oklahoma University Health Sciences Center, the Veterans Administration Medical Center of Oklahoma City and Oklahoma Medical Research Foundation, Oklahoma City, Oklahoma 73104; and the

Department of Medicine, Division of Rheumatology, University of Texas Health Sciences Center, Houston, Texas 77225

\begin{abstract}
Antibodies to aminoacyl-tRNA synthetases (anti-Jo-1, antiPL-7, anti-PL-12) have been found in the serum of some patients with polymyositis (PM). Patients with these antibodies have an unusually high rate of interstitial lung disease (ILD) in association with their PM. Two patients (K.J. and B.T.) with severe ILD and PM were found to have antibodies to a cytoplasmic antigen, but tests to determine whether the antigen was an aminoacyl-tRNA synthetase were negative, including tests of $\mathrm{KJ}$ serum for inhibitory effects on the $\mathbf{2 0}$ synthetases. KJ immunoprecipitates did not contain tRNA, in contrast to antisynthetase sera. When IgG samples were added to a reticulocyte in vitro translation system at a concentration of 0.3 $\mathrm{mg} / \mathrm{ml}$, KJ IgG inhibited globin mRNA translation by $98 \%$, while anti-Jo-1 IgG inhibited $62 \%$ and normal IgG had little effect. Thus, both anti-KJ and the antisynthetases are directed at antigens that are involved in translation and protein synthesis, and both are associated with the syndrome of lung disease and PM. This syndrome may be associated with antibodies to translation-related proteins in general, which may have implications for the link of PM and enteroviruses, which are mRNA viruses.
\end{abstract}

\section{Introduction}

Polymyositis (PM) ${ }^{1}$ and dermatomyositis (DM) are inflammatory myopathies whose pathogeneses appear to involve autoimmunity (1), one manifestation of which is the frequent finding of serum autoantibodies. Routine testing with indirect immunofluorescence and Ouchterlony immunodiffusion can detect autoantibodies in the serum of almost $90 \%$ of patients with PM and DM (2). Some of these autoantibodies occur almost exclusively in patients with myositis (3). These include

Presented in part at the Annual Meeting of the American Rheumatism Association, June 1987.

Address reprint requests to Dr. Targoff, Arthritis/Immunology Section, Oklahoma Medical Research Foundation, 825 N. E. 13th Street, Oklahoma City, OK 73104.

Received for publication 13 April 1988 and in revised form 1 February 1989.

1. Abbreviations used in this paper: CK, creatine kinase; DM, dermatomyositis; FVC, forced vital capacity; ILD, interstitial lung disease; PM, polymyositis; SRP, signal recognition particle.

J. Clin. Invest.

(c) The American Society for Clinical Investigation, Inc. 0021-9738/89/07/0162/11 \$2.00

Volume 84, July 1989, 162-172 antibodies to histidyl-tRNA synthetase $(4,5)$ (labeled anti-Jo-1 [6]), and antibodies to the unidentified proteins labeled PMScl (7) and Mi-2 (8). None of these specificities is found randomly in myositis patients, but all tend to be associated with particular clinical features, suggesting that they might help to define subgroups of patients $(3,9)$. Similarly, autoantibodies to ribonucleoprotein complexes are associated with characteristic clinical subgroups in systemic lupus erythematosus (SLE) (10).

PM and DM have also been divided into subgroups based on clinical criteria $(11,12)$, including the presence of a rash (DM), an associated malignancy, childhood onset, or an associated connective tissue disease. This clinical heterogeneity may indicate that PM and DM represent more than one disease, and it is possible that patients in one subgroup are more homogeneous. The groups defined by the myositis-associated autoantibodies, however, do not necessarily conform to the clinically defined subgroups noted above. Anti-Mi-2, for example, is exclusively seen in DM, but is seen in only $20 \%$ of that group, and may be seen in adult DM alone, DM with malignancy, or juvenile DM (8). Of the autoantibody associated clinical subgroups, that of anti-Jo-1 is the best defined. Anti-Jo-1 is the most common myositis associated antibody, being present in $\sim 20 \%$ of myositis patients in most studies (2-4, 6-7, 13-14). Most patients with anti-Jo-1 have PM, without the DM rash $(2,3,6,9,13-15)$, although a higher proportion in DM was found in one population (16). Also, there is consistent evidence that the majority of patients with anti-Jo-1 have diffuse interstitial lung disease (ILD) along with their PM (15-20). The ILD can be severe and fatal, and dominate the patient's clinical picture. The presence of this complication has not been used to distinguish clinical subgroups of patients in most classifications. An additional genetic marker associated with this subgroup is HLA-DR3, which in one study (13) was present in $64 \%$ of anti-Jo-1 positive patients, compared to only $22 \%$ of anti-Jo- 1 negative patients.

The enzyme, histidyl-tRNA synthetase, to which anti-Jo-1 is directed, is one of the aminoacyl-tRNA synthetases, a group of cytoplasmic enzymes that catalyze the attachment of a particular amino acid to its cognate tRNA (and may have other functions) (21). There is a distinct enzyme in the cytoplasm for each amino acid (as well as a second in the mitochondria). Antibodies to two of the other aminoacyl-tRNA synthetases have been reported in myositis patients, anti-threonyl-tRNA synthetase (anti-PL-7) $(22,23)$ and anti-alanyl-tRNA synthetase (anti-PL-12) (24). Although exceptions occurred, almost all the patients in whom these antibodies were found had myositis $(9,22,24)$, and most also had ILD (9). We have recently presented evidence of antibodies to isoleucyl-tRNA synthetase in two patients and glycyl-tRNA synthetase in one (25). There were signs of myositis in all three patients, and severe ILD in one with anti-ile-tRNA synthetase. Additional 
features have also been noted that were more common in patients with antibodies to synthetases than in others with myositis, including arthritis $(9,15)$ and Raynaud's phenomenon (9). Thus, all antisynthetases may be associated with the same clinical subgroup.

The current study began with the finding of a patient, K.J., with severe ILD and PM, and a high titer anticytoplasmic antibody on indirect immunofluorescence. A second patient, B.T., had a similar syndrome and an identical line in immunodiffusion. This antibody, however, was found not to be antiJo-1, anti-PL-7, or anti-PL-12. We suspected that these patients belonged to the same clinical subgroup as that of patients with antisynthetases. We felt that it was particularly important to learn more about this cytoplasmic antigen, because it could give another perspective on the features that lead to antigenicity in this syndrome. In this study we defined and partially characterized the $\mathrm{KJ}$ antigen, and looked for a relationship of the $\mathrm{KJ}$ antigen to other targets of autoantibodies in these patients.

\section{Methods}

\section{Patients}

Case 1. K.J., a 30-yr-old black woman, developed shortness of breath on exertion and new onset Raynaud's phenomenon 5 mo before hospital admission. By the time of admission, she could walk only 6-8 m before resting. She was unaware of having had any rash or muscle weakness, and did not report dry eyes or dry mouth. She had never smoked. On examination, her respiratory rate was $24 / \mathrm{min}$ with some distress, and there were fine bibasilar rales and an accentuated P2. Mild to moderate proximal muscle weakness was present, as well as mild pigmentary changes on the face that were not typical of DM. There were no other rashes or sclerodactyly. Creatine kinase (CK) level was 3,330 U/liter (55.51 $\mu \mathrm{kat} / \mathrm{liter}$ ) of which 3,157 U/liter (52.63 $\mu \mathrm{kat} / \mathrm{liter}$ ) was MM. Serum protein electrophoresis showed a mild polyclonal increase in gamma globulin (IgG level $=2,150 \mathrm{mg} / \mathrm{dl}$ ). Tests of rheumatoid factor and antimitochondrial antibodies were negative, and $\mathrm{C} 3$ and $\mathrm{C} 4$ were normal. The erythrocyte sedimentation rate was 38 $\mathrm{mm} / \mathrm{h}$. Thyroid function tests were normal. $\mathrm{PO}_{2}(\mathrm{aB})$ was $54 \mathrm{mmHg}$ $(7.2 \mathrm{kPa})$. The forced vital capacity (FVC) was 0.85 liter $(21 \%$ of predicted) without obstruction $\left(\mathrm{FEV}_{1} / \mathrm{FVC}=84 \%\right)$. There was a diffuse interstitial pattern on chest $x$ ray, and evidence of primary myopathy with suggestion of necrosis on electromyography. A muscle biopsy was normal. The clinical diagnosis was diffuse interstitial lung disease secondary to $P M$, and she was treated with prednisone at $1 \mathrm{mg} / \mathrm{kg}$ per d ( $90 \mathrm{mg} / \mathrm{d}) .3 \mathrm{mo}$ later, while still taking $90 \mathrm{mg} / \mathrm{d}$ prednisone, her CK level had fallen to $320 \mathrm{U} / \mathrm{liter}$ ( $5.33 \mu \mathrm{kat} / \mathrm{liter})$ and her strength was clinically normal. The interstitial pattern on chest $\mathrm{x}$ ray persisted, her $\mathrm{pO}_{2}$ was $67 \mathrm{mmHg}(8.9 \mathrm{kPa})$, and her forced vital capacity was 0.98 liter. 18 mo later, her CK level was normal and the lung disease had improved, although the Raynaud's phenomenon persisted. She remained on prednisone, but her dosage had been reduced to $30 \mathrm{mg} / \mathrm{d}$.

Case 2. B.T., a 53-yr-old white housewife, was well until June, 1983 when she experienced increasing fatigue, particularly on climbing stairs, brushing her hair, and performing general household activities. She had no Raynaud's phenomenon or dry eyes, and denied smoking. Her symptoms progressed over a period of weeks until she was not able to get out of bed unaided. Her respirations were $24 / \mathrm{min}$. There was generalized muscle weakness, especially of the shoulder girdle, thighs, and paraspinal muscles. Chest $x$ ray revealed a diffuse bilateral infiltrate, especially at the bases. Laboratory studies showed a mild normocytic normochromic anemia with a hemoglobin of $11.0 \mathrm{~g} / \mathrm{dl}$ and elevations of the CK to 4,000 U/liter (66.68 $\mu \mathrm{kat} /$ liter) (normal 50-250 $\mathrm{U} / \mathrm{liter}$ ), the AST to $150 \mathrm{U} / \mathrm{liter}$ (2.50 $\mu \mathrm{kat} / \mathrm{liter}$ )-(normal 7-40 U/liter), and ALT to $300 \mathrm{U} /$ liter ( $5.00 \mu \mathrm{kat} / \mathrm{liter}$ ) (normal 7-40 U/liter). There was no myoglobin in the urine. The rheumatoid factor and antinuclear antibody were negative. Complement studies were normal. Electromyographic findings were compatible with PM and indicated insertional irritability, increased motor unit potentials, sharp spikes, and low amplitude polyphasic potentials. Histopathology of the deltoid showed muscle degeneration with necrosis and areas of regeneration. The $\mathrm{pO}_{2}$ was $70 \mathrm{mmHg}(9.3 \mathrm{kPa})$, the forced vital capacity was 1.5 liter ( $55 \%$ of predicted value), and the $\mathrm{FEV}_{1} / \mathrm{FVC}$ ratio was $85 \%$. A diagnosis of PM with pulmonary infiltrative disease was made. The patient was treated with $80 \mathrm{mg} / \mathrm{d}$ i.v. prednisolone. This dose was titered according to her clinical response and CK levels. Within 4 wk the CK had dropped to $500 \mathrm{U} / \mathrm{liter}(8.34 \mu \mathrm{kat} / \mathrm{liter})$ and the patient was on 40 $\mathrm{mg} / \mathrm{d}$ prednisone orally. After $12 \mathrm{wk}$ of therapy, there was marked improvement in muscle strength, her CK had dropped to $300 \mathrm{U} /$ liter $(5.00 \mu \mathrm{kat} / \mathrm{liter})$, and the prednisone dose decreased to $15 \mathrm{mg} / \mathrm{d}$.

Evaluation for headache in 1984 revealed a right parietal meningioma and a pericallosal aneurysm. The tumor was surgically excised and the aneurysm successfully repaired. In 1985 she was rehospitalized with an exacerbation of PM. At this stage she complained of Raynaud's phenomenon precipitated by exposure to cold temperatures. Examination of the hands revealed taut skin and sclerodactyly with telangiectasiae. $\mathrm{X}$ ray of the chest showed diffuse pulmonary fibrosis with bibasilar honeycombing. On esophageal manometry there was a severe motility disorder of the lower two-thirds of the esophagus and the lower esophageal sphincter, with normal pharyngeal and cricopharyngeal muscles. Rheumatoid factor was still absent but the antinuclear antibody test was reported as positive with a titer of $1 / 160$.

Sera. Serum or plasma from patient K.J. served as the standard for the $\mathrm{KJ}$ antibody. Other samples tested in the study came from a bank of sera collected over $15 \mathrm{yr}$ from patients with myositis. Patients were considered to have myositis if they satisfied the criteria of Bohan and Peter $(11,12)$ for definite or probable PM or DM. Immunoglobulin from a lupus serum known to contain antibody to the ribosomal $\mathbf{P}$ proteins (26) (kindly provided by Dr. Keith Elkon) was also tested. Serum samples were stored at $-20^{\circ} \mathrm{C}$.

Aminoacylation inhibition. $\mathrm{KJ}$ serum was tested for antibodies to aminoacyl-tRNA synthetases by determining its ability to inhibit the aminoacylation reactions of the individual synthetases. Histidine aminoacylation inhibition was performed as described previously (14). Aminoacylation reactions for the other amino acids were set up using similar conditions. 1-4 $A_{260} U$ of calf liver tRNA preparation (Boehringer-Mannheim, Indianapolis, IN) contained enough tRNA for most of the amino acids (although $E$. coli tRNA was used for the alanine reaction). The test amino acid was included in labeled form $\left({ }^{3} \mathrm{H}\right.$ except ${ }^{14} \mathrm{C}$-Asn and $\left.{ }^{35} \mathrm{~S}-\mathrm{Cys}\right)$ and diluted with unlabeled amino acid so that the total concentration $(10-20 \mu \mathrm{M})$ was in significant excess of the approximate tRNA accepting capacity for that amino acid. Calf liver extract, prepared using the method of Pearson (27) modified as previously described (14), was used as the enzyme source (partial purification by DEAE was used for some enzymes). The limiting concentration of synthetase preparation was determined empirically for each individual aminoacylation reaction, by preparing a dilution curve, in order that any inhibition of enzyme activity was reflected in the results. To test inhibition, $6 \mu \mathrm{l}$ of the preparation containing the enzyme activity was preincubated with $3 \mu \mathrm{l}$ of $\mathrm{KJ}$ serum at $1 / 10$ dilution (diluted in $0.15 \mathrm{M} \mathrm{NaCl}, 0.01 \mathrm{M}$ phosphate buffer $\mathrm{pH} 7.2$ [PBS]) for $1-2 \mathrm{~h}$ at $4^{\circ} \mathrm{C}$. The remainder of the reaction was as previously described (14), with $5-\mu 1$ aliquots taken at 10 and 20 min for counting. In most cases, the 10-min readings were used for calculating inhibition. $\{[($ Counts without serum) - (counts with test serum) $] /$ (counts without serum) $\} \times 100$ represents the percent inhibition, and is a reflection of the amount of antibody. Greater than $40 \%$ inhibition was considered significant, based on experience with other anti-synthetases, since even low titer antibodies to other synthetases inhibit $>80 \%$ in almost every case $(14,22,28)$.

Protein A-assisted immunoprecipitation. The method of Forman et al. (29) for immunoprecipitation from unlabeled cell extracts was used. $2 \mathrm{mg}$ of protein A-Sepharose (Pharmacia Fine Chemicals, Piscataway, 
NJ) were used per test, and washed in $0.01 \mathrm{M}$ Tris buffer pH 8.0, with $0.5 \mathrm{M} \mathrm{NaCl}$ and $0.1 \% \mathrm{NP}-40.10 \mu \mathrm{l}$ serum in $500 \mu \mathrm{l}$ of the same buffer was incubated with the beads with gentle mixing, for at least $2 \mathrm{~h}$ at $4^{\circ} \mathrm{C}$. The beads were then washed and used for immunoprecipitation. HeLa cell extract for immunoprecipitation was prepared according to Forman et al. (29) from cells grown in $150 \mathrm{~cm}^{2}$ flasks, using the equivalent of 1 flask for four samples sonicated in $0.15 \mathrm{M} \mathrm{NaCl}$ in $0.05 \mathrm{M}$ Tris$\mathrm{HCl}$ buffer at $\mathrm{pH}$ 7.4. The extract was precleared with protein A-Sepharose that had not been coated with antibody, to decrease nonspecific binding. Coated protein A-Sepharose was combined with $500 \mu \mathrm{l} \mathrm{HeLa}$ cell extract, and incubated at least $2 \mathrm{~h}$ at $4^{\circ} \mathrm{C}$. The phenol-extracted immunoprecipitates were analyzed on $7 \mathrm{M}$ urea-10\% polyacrylamide gels, which were stained with silver stain (Bio-Rad Laboratories, Richmond, CA).

In vitro translation. A nuclease-treated rabbit reticulocyte lysate system similar to that of Jackson and Hunt (30) was used (from a commercial kit from Bethesda Research Laboratories, Gaithersburg, MD). A standard translation reaction with globin messenger RNA was set up, with $\left[{ }^{3} \mathrm{H}\right]$ leucine as the labeled amino acid (leucine is represented in rabbit globin [31]). IgG purified from patient serum (see below) was dialyzed against water, and concentrated. In order to measure inhibition, the level of translation in the presence of patient IgG was compared to translation in the presence of normal IgG or in the absence of added IgG. $9 \mu \mathrm{l}$ of lysate was preincubated with $9 \mu \mathrm{l}$ of the IgG solution in water (or water alone as control), usually at $1 \mathrm{mg}$ $\mathrm{IgG} / \mathrm{ml}$. Since it is possible that the $\mathrm{IgG}$ could have contamination with ribonucleases, $1 \mathrm{U} / \mu \mathrm{l}$ of placental ribonuclease inhibitor was also added, which was reported to be effective for this purpose (32). The antibody was preincubated with all reaction components except the mRNA for $30 \mathrm{~min}$ at $4^{\circ} \mathrm{C}$. The mRNA was then added to start the reaction (completing a 30- $\mu$ l reaction volume), which was otherwise carried out as in kit directions, including addition of pancreatic ribonuclease at $60 \mathrm{~min}$. Two aliquots of $5 \mu \mathrm{l}$ each were taken at $75 \mathrm{~min}$ and counted as for aminoacylation except that an additional bleaching step was added (formic acid and peroxide [33]).

For some experiments, instead of adding IgG directly to the reaction mixture, protein A-Sepharose beads coated with antibody were preincubated with the lysate. 5-7 $\mathrm{mg}$ of protein A-Sepharose were washed and preincubated with $100 \mu \mathrm{l}$ of serum in $500 \mu \mathrm{l}$ of $0.02 \mathrm{M}$ Tris buffer pH 7.2 with $0.15 \mathrm{M} \mathrm{NaCl}$ (or, where indicated, $500 \mu \mathrm{l} \mathrm{of} \mathrm{IgG} \mathrm{at} 1$ $\mathrm{mg} / \mathrm{ml}$ ). The Sepharose was washed again three times in buffer and two times in water, and 30-40 $\mu 1$ lysate and an equal volume of sterile water were added to the pelleted Sepharose. The tube was stirred frequently over $30 \mathrm{~min}$ incubation at $4^{\circ} \mathrm{C}$. The Sepharose was then centrifuged out and the lysate was used for translation, and compared to lysate that had been treated with Sepharose coated with other sera or no serum. For further confirmation that an antigen/antibody reaction was responsible for the observed effects, the 5-7 mg of protein A-Sepharose beads were coated with $100 \mu \mathrm{l}$ of serum and incubated with HeLa extract (or HeLa extract buffer as control) prepared as in the immunoprecipitation procedure described above, and the washing steps repeated, before incubation with the lysate. Anti-KJ-coated Sepharose, with and without incubation with HeLa extract, was compared to Sepharose coated with normal IgG or anti-Jo-1 controls.

Partial purification of the $K J$ antigen. The $\mathrm{KJ}$ antigen was purified from bovine liver, obtained fresh, transported on ice to the laboratory, and either used immediately or frozen and stored at $-40^{\circ} \mathrm{C}$ until used. Extract was prepared at $4^{\circ} \mathrm{C}$ by homogenization by blender (at medium speed) in PBS with $0.01 \mathrm{M}$ sodium azide and 0.001 M PMSF (2 vol PBS/weight of tissue), followed by centrifugation in a Sorvall SS-34 rotor at $20,000 \mathrm{rpm} \times 1 \mathrm{~h}$. The major step in purification was affinity chromatography, which was performed using a method similar to that previously described $(8,14)$. The IgG fraction was purified from $50 \mathrm{ml}$ of $\mathrm{KJ}$ serum using DEAE (see below). $\mathrm{KJ}$ IgG was coupled to Affi-gel (Bio-Rad Laboratories) hydroxysuccinamide-agarose in $0.1 \mathrm{M}$ bicarbonate buffer at $\mathrm{pH} 8.3$, with $>90 \%$ coupling. The immunoadsorbent was washed extensively, including with the intended eluting agent ( $3 \mathrm{M}$ $\mathrm{MgCl}_{2}$ ). Later experiments were performed using a second column prepared in a similar manner (from $75 \mathrm{ml}$ of serum taken at a time when the titer was slightly lower). After liver extract was applied to the column in excess of adsorbing capacity, the column was extensively washed with $0.5 \mathrm{M} \mathrm{NaCl}$ in $0.05 \mathrm{M}$ Tris buffer at pH 7.2 with $0.01 \mathrm{M}$ $\mathrm{Na}$ azide and $0.0001 \mathrm{M}$ PMSF (TBS), and eluted with $3 \mathrm{M} \mathrm{MgCl}_{2}$. Fractions containing protein (as determined by optical density at 280 $\mathrm{nm}$ ) were pooled and concentrated (by ultrafiltration) and applied to a Superose 12 gel filtration column using Fast Protein liquid chromatography (FPLC; Pharmacia Fine Chemicals) with TBS as running buffer. Antigenic activity was monitored by ELISA.

$E L I S A$. To detect the presence of $\mathrm{KJ}$ antigen in purified preparations and column fractions, a standard indirect ELISA was used, similar in design to that which was described previously $(8,14) .10-15 \mu l$ of pooled active fractions from FPLC were added to the microtiter well, followed by PBS to bring the volume to $100 \mu \mathrm{l}$. After overnight incubation, plates were washed in PBS with $0.05 \%$ Tween- 20 and blocked with 2\% BSA in PBS. The ELISA activity of $\mathrm{KJ}$ serum against each fraction was compared to that of normal, BT, and anti-Ro/SSA sera for the same fraction (sera were diluted $1 / 300$ in blocking solution). After incubation and washing, goat anti-human IgG (gamma chain specific) (or $F\left(a b^{\prime}\right)_{2}$ fragments of this antibody) conjugated to alkaline phosphatase (Sigma Chemical Co., St. Louis, MO) was applied, diluted in the washing solution. After incubation and washing, para-nitrophenyl phosphate substrate was applied. ELISA for anti-Ro/SSA was performed as previously described (34).

Polyacrylamide gel electrophoresis and Western blotting. SDSPAGE was performed according to Laemmli (35), modified as previously described $(8,14)$. For protein staining, the silver stain was used. Most samples were dialyzed against water and concentrated, before addition of $1 / 3 \mathrm{vol}$ of fourfold concentrated sample buffer, (containing beta-mercaptoethanol except as noted). Western blotting was performed according to Towbin (36), with some modification similar to that described previously (14). Proteins were transferred to nitrocellulose in $0.025 \mathrm{M}$ Tris- $0.192 \mathrm{M}$ glycine buffer at $\mathrm{pH} 8.3$ with $20 \%$ methanol. The nitrocellulose was then blocked with 5\% BSA in $0.01 \mathrm{M}$ Tris, $0.15 \mathrm{M} \mathrm{NaCl}$, pH 7.4. Test sera were diluted $1 / 100$ in blocking buffer. The nitrocellulose was washed with $0.01 \mathrm{M}$ Tris- $0.15 \mathrm{M}$ saline buffer pH 7.4 with and without $0.05 \%$ Triton X-100. Conjugate (same as for ELISA) was then applied, diluted 1/500 in blocking buffer, followed by BCIP/NBT alkaline phosphatase substrate (KierkegaardPerry).

Isolation of ribosomes. Ribosomes derived from microsomes were isolated from rat liver by the method of Moldave and Sadnik (37). In this method, microsomes were obtained by homogenization in $0.35 \mathrm{M}$ sucrose (in $35 \mathrm{mM} \mathrm{KHCO}_{3}, 20 \mathrm{mM} \mathrm{K} \mathrm{HPO}_{4}, 25 \mathrm{mM} \mathrm{KCl}, 4 \mathrm{mM}$ $\mathrm{MgCl}_{2}$ buffer at $\mathrm{pH} 7.6$ ), and centrifugation for $2 \mathrm{~h}$ at $100,000 \mathrm{~g}$. The sediment was resuspended in $0.5 \mathrm{M} \mathrm{NH}_{4} \mathrm{Cl}$ (in $50 \mathrm{mM}$ Tris $\mathrm{HCl}$ buffer at pH 7.6 with $10 \mathrm{mM} \mathrm{MgCl}_{2}$, and $6 \mathrm{mM}$ mercaptoethanol), treated with deoxycholate (final concentration 1.5\%), and centrifuged through a discontinuous sucrose gradient ( 0.5 and $1.0 \mathrm{M}$ sucrose). The postmicrosomal supernatant was further centrifuged for $16 \mathrm{~h}$ at $80,000 \mathrm{~g}$ to remove remaining subunits. The resulting supernatant was referred to as the postribosomal supernatant. The ribosomes were resuspended in $0.35 \mathrm{M}$ sucrose (in $50 \mathrm{mM}$ Tris buffer at $\mathrm{pH} 7.6$ with $50 \mathrm{mM} \mathrm{NH}_{4} \mathrm{Cl}, 4$ $\mathrm{mM} \mathrm{MgCl}$, and $1 \mathrm{mM}$ DTT).

Fluorescence inhibition. Since Western blots and immunodiffusion were not sensitive enough to detect the $\mathrm{KJ}$ antigen in subcellular fractions (ribosomes, postribosomal supernatant, whole extract, etc.), the technique of fluorescence inhibition was used. In this experiment, $\mathrm{KJ}$ serum was absorbed with the test extract before using the $\mathrm{KJ}$ serum in indirect immunofluorescence. Indirect immunofluorescence titer would be decreased if antigen were present in the test extract, and able to bind the anti-KJ antibodies. This method was also used to confirm that the cytoplasmic antigen had been recovered from the affinity column (by adding affinity purified antigen to $\mathrm{KJ}$ serum before using the serum in indirect immunofluorescence). Since $\mathrm{KJ}$ serum reacted in immunodiffusion with the affinity purified antigen, this evidence that the affinity purified antigen preparation contained the cytoplasmic 
antigen provided further evidence that the antibody detected by immunodiffusion was the same as the antibody giving a cytoplasmic pattern of indirect immunofluorescence.

$\mathrm{KJ}$ serum was diluted $1 / 100$ in PBS. One part diluted $\mathrm{KJ}$ serum was mixed with nine parts test extract (or PBS for control), and the samples were tested by indirect immunofluorescence using HEp-2 cell substrate. Any decrease in fluorescence activity represented the presence of $\mathrm{KJ}$ antigen in the extract. Active extracts were then serially diluted and retested to estimate the $\mathrm{KJ}$ antigen content. The $\mathrm{KJ}$ serum sample was used at 1/1,000 final dilution because it was not maximally active, but was still strong. The indirect immunofluorescence procedure, using commercial HEp-2 slides (Breit Laboratories, West Sacramento, CA), was otherwise performed as usual (2).

Purification of IgG. In some experiments, human Cohn fraction II (Sigma) was used for normal human IgG, while in others, as indicated, IgG was purified from normal serum as from test serum. Standard anti-Jo-1 IgG was purified from one of the three sera out of 24 with the highest titer of anti-Jo- 1 as determined in a recent study (14) using both ELISA and histidine aminoacylation inhibitory activity. IgG was purified from test sera by one of two methods. First, serum was dialyzed against $0.2 \mathrm{M}$ Tris- $\mathrm{HCl}$ buffer at $\mathrm{pH} 7.4$, and applied to a similarly equilibrated DEAE column (DE-52; Whatman Inc., Clifton, NJ) of three- to fivefold volume, with collection of the effluent as IgG. This method was also used for preparation of IgG for the affinity column. In the second method, serum was applied to protein A-Sepharose (Pharmacia) (approximately fivefold gel/serum ratio) that had been equilibrated with TBS. The column was washed with TBS, and IgG was then eluted with glycine- $\mathrm{HCl}$ buffer at $\mathrm{pH} \mathrm{3.0,} \mathrm{and} \mathrm{dialyzed} \mathrm{against} \mathrm{water}$ for translation studies. For absorption of the IgG preparation with protein A-Sepharose, protein A purified IgG was mixed 1:1 with TBS and separated into fractions 1 and 2. A portion of fraction 1 was applied to a fresh protein A-Sepharose column. The flow-through fraction from this column and fraction 2 were dialyzed against water and concentrated (the flow-through of fraction 1 was concentrated twice as far as fraction two).

Other methods. Protein concentrations were determined by the Bio-Rad protein assay, based on the method of Bradford (38), except for IgG concentrations, which were determined by optical density at $280 \mathrm{~nm}$. Ouchterlony immunodiffusion and indirect immunofluorescence were performed as previously described (2).

\section{Results}

Serological screening studies. Indirect immunofluorescence with $\mathrm{KJ}$ serum was negative using a mouse kidney substrate, but strongly positive for cytoplasmic fluorescence using HEp-2 cells (Fig. 1). The anticytoplasmic antibody titer was $1 / 29,160$ before therapy, and still showed a titer of 1/3,240 one year later. No antibodies to single stranded or double stranded DNA were present. Ouchterlony immunodiffusion of $\mathrm{KJ}$ serum against bovine spleen extract showed a precipitin line that was nonidentical with standard sera for antibodies to Ro/ SSA, La/SSB, U ${ }_{1}$ RNP, Sm, Jo-1, Mi-2, Ku, and PM-Scl, as well as antiribosomal $P$. This line was compared to unidentified lines that have been found previously in routine testing of other myositis sera, and only one additional patient, BT, gave an identical precipitin line. Indirect immunofluorescence on HEp-2 cells with BT serum showed an exclusively cytoplasmic

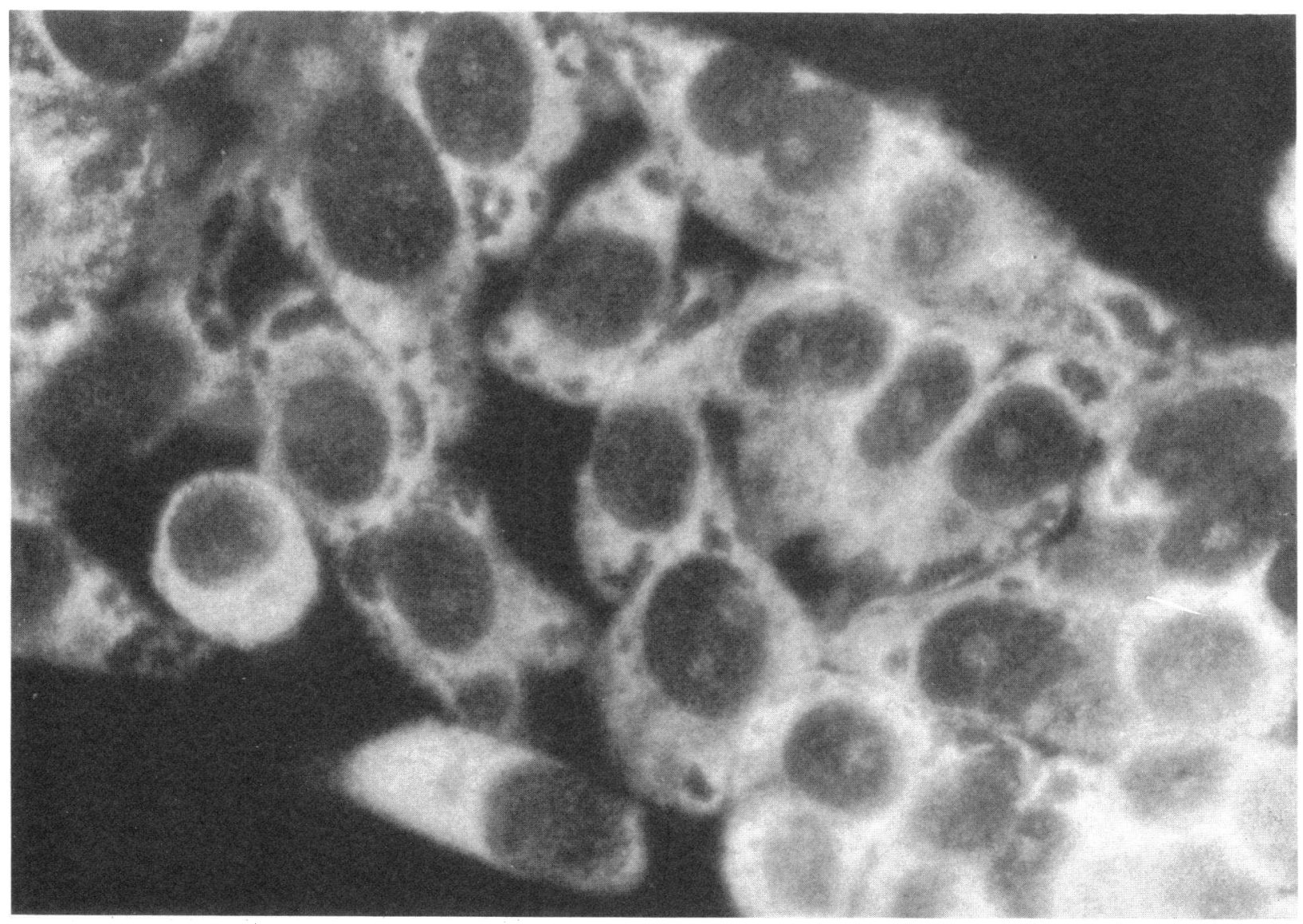

Figure 1. Indirect immunofluorescence of $\mathrm{KJ}$ serum on acetone fixed $\mathrm{HEp}-2$ cells. Results with 1/40 dilution are shown, but this sample could be titered to $1 / 3240$. 
pattern to a dilution of $1 / 3,240$, with no staining of the nucleus.

Testing for anti-synthetase antibodies. Because of the presence of myositis in association with interstitial lung disease in both patients, it was suspected that the anticytoplasmic antibody was directed at an aminoacyl-tRNA synthetase. Both $\mathrm{KJ}$ and BT sera were negative for anti-Jo- 1 by the sensitive ELISA method with affinity purified Jo-1 as antigen (14). KJ and BT sera were also tested for antibody to histidyl-tRNA, threonyltRNA, and alanyl-tRNA synthetase by aminoacylation inhibition, and the difference from controls was not considered significant for either serum (all reported patient sera with such antibodies inhibit the respective enzyme). There was slightly more inhibition of threonyl-tRNA synthetase by BT serum (by $\sim 15 \%$ ), but still well below the $25 \%$ significance level (all previous sera found to contain antibodies to this enzyme have inhibited $>80 \%$ (28). Thus, if anti-KJ was an antisynthetase, it was not one that had been previously described.

Aminoacylation inhibition data for $\mathrm{KJ}$ serum for the 20 amino acids is shown in Table $I$. The level of significant inhibition, based on screening a large number of sera for anti-Jo-1 and anti-PL-7 by this method, was considered to be $40 \%$. The largest amount of inhibition by $\mathrm{KJ}$ serum for any of the reactions tested was $16.8 \%$ (for proline). Thus, there was no evidence of significant inhibition of the activity of any of the synthetases, indicating that there was no evidence for antibody. Since later evidence demonstrated that anti-KJ inhibited the function of the $\mathrm{KJ}$ antigen, it was concluded that the cyto-

Table I. Aminoacylation Inhibition by KJ Serum

\begin{tabular}{lrrr}
\hline Amino acid & CPM-NS & CPM-KJ & \%INH \\
\hline Ala & 2,180 & 1,857 & 14.8 \\
Arg & 223,627 & 201,196 & 10.0 \\
Asn & 7,190 & 7,194 & -0.1 \\
Asp & 5,531 & 5,955 & -7.7 \\
Cys & 2,009 & 2,113 & -5.2 \\
Gln & 5,531 & 5,131 & 7.2 \\
Glu & 9,132 & 9,577 & -4.9 \\
Gly & 2,144 & 2,320 & -8.2 \\
His & 4,770 & 4,366 & 8.5 \\
Iso & 4,188 & 4,431 & -5.8 \\
Leu & 2,496 & 2,517 & -0.9 \\
Lys & 19,655 & 20,489 & -4.2 \\
Met & 7,619 & 7,028 & 7.8 \\
Phe & 6,298 & 6,132 & 2.6 \\
Pro & 36,439 & 30,308 & 16.8 \\
Ser & 15,527 & 15,797 & -1.7 \\
Thr & 2,923 & 3,370 & -15.3 \\
Try & 14,766 & 14,133 & 4.3 \\
Tyr & 14,436 & 13,953 & 3.3 \\
Val & 37,174 & 38,029 & -2.3 \\
& & & \\
\hline
\end{tabular}

The effect of $\mathrm{KJ}$ serum on the activity of the 20 aminoacyl-tRNA synthetases is shown. CPM, counts per minute in the TCA precipitate, which represents the amount of aminoacyl-tRNA formed and reflects the activity of the respective enzyme under the conditions of the assay. CPM-NS, CPM when no serum is added; CPM-KJ, CPM in the presence of $1 / 100$ parts $\mathrm{KJ}$ serum $(3 \mu \mathrm{l} 1 / 10$ diluted serum added to the reaction mixture). \%INH, \% inhibition, calculated as: [(cpm-NS - cpm-KJ)/cpm-NS] $\times 100$. plasmic $\mathrm{KJ}$ antigen was not one of the aminoacyl-tRNA synthetases.

Immunoprecipitation. As seen in Fig. 2, specific immunoprecipitation of tRNA by $\mathrm{KJ}$ serum could not be demonstrated. Previous studies have consistently found that autoantibodies to any of the five antigenic aminoacyl-tRNA synthetases immunoprecipitate their respective cognate tRNAs (4, 22-25, 32). This is demonstrated in Fig. 2, in which anti-Jo-1 and anti-PL-7 sera were found to precipitate very strong sharp bands containing different tRNAs. Lack of precipitation of tRNA supports the conclusion that $\mathrm{KJ}$ antigen is not an aminoacyl-tRNA synthetase. It also may be concluded that $\mathrm{KJ}$ antigen does not form stable complexes with tRNA under the conditions of the immunoprecipitation, as do certain other antigens to which myositis sera have been found (32). As seen in Fig. 2, BT precipitates a faint single band of very small RNA which has not been identified (some background tRNA is seen, but the smallest, furthest migrating band is significant and reproducible). This could be due to a coexistent antibody to a tRNA-related antigen, but is unlikely to be the anti-KJ in BT serum, because $\mathrm{KJ}$ serum did not show this tRNA despite its much higher titer of anti-KJ (see ELISA data below).

$\mathrm{KJ}$ serum immunoprecipitated bands of RNA corresponding to those of the Ro/SSA RNAs, as evident by comparison to the standard anti-Ro/SSA serum in Fig. 2. The finding that KJ serum had anti-Ro/SSA in addition to anti-KJ antibodies was confirmed by ELISA. KJ serum had $5.5 \times 10^{5}$ activity units on anti-Ro/SSA ELISA, significantly higher than the average normal of $8.0 \times 10^{3} \mathrm{U}$. No anti-Ro/SSA precipitin line was present by immunodiffusion, but it is common for sera with this level of anti-Ro/SSA ELISA activity to fail to form an anti-Ro/SSA precipitate (34). BT serum did not precipitate the Ro RNAs, and BT serum was negative for anti-Ro/SSA by ELISA. The precipitation of strong Ro RNA bands by $\mathrm{KJ}$

\section{$\begin{array}{lllllll}1 & 2 & 3 & 4 & 5 & 6 & 7\end{array}$}

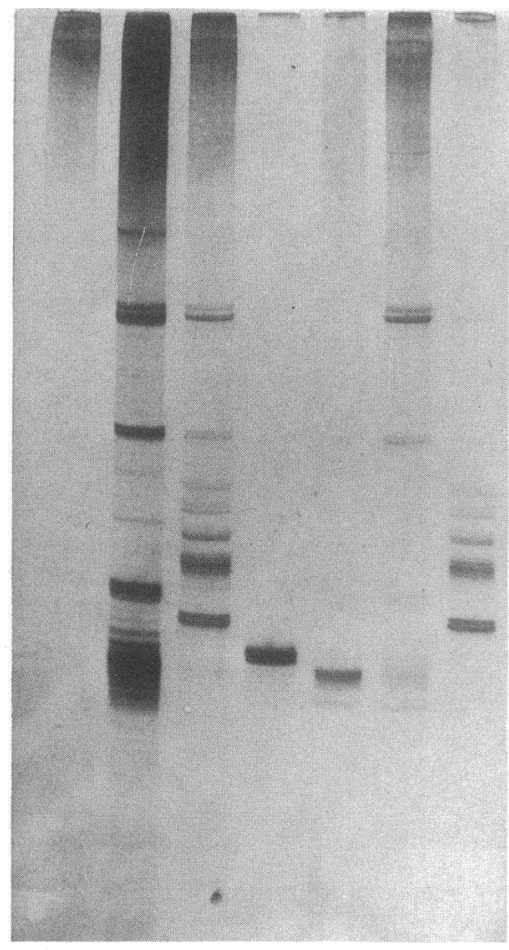

Figure 2. $7 \mathrm{M}$ urea, $10 \%$ polyacrylamide gel electrophoresis of protein A-immunoprecipitates, stained with silver stain. Lane 2 contained total nucleic acids. Other lanes represent phenol-extracted immunoprecipitates obtained using ( $a$ ) normal serum; (b) $\mathrm{KJ}$ serum; (c) serum from a PM patient $(C D)$ with antiJo- 1 by ID and ELISA (this serum inhibits histidyl-tRNA synthetase); (d) serum from a PM patient (VP) with antiPL-7 by ELISA (this serum inhibits threonyltRNA synthetase); (e) BT serum; $(f)$ serum from a patient with SLE with anti-Ro/SSA. 
serum, with weak anti-Ro/SSA activity, serves as an internal positive control, indicating sensitive detection of precipitated RNA, and supporting the negative result for $\mathrm{KJ}$ with respect to tRNA.

Fig. 2 shows that both $\mathrm{KJ}$ and BT sera immunoprecipitated bands of $\sim 5.0$ and $5.8 \mathrm{~S}$ that are likely to be the small ribosomal RNAs. There is only a modest amount of precipitation of these RNAs with $\mathrm{KJ}$ and BT sera despite the abundance of these RNAs in the extract (as shown in the total nucleic acid lane), and in some runs these RNAs are not evident at all. These findings suggest that precipitation of the ribosomal RNAs by KJ and BT may have represented a partial or intermittent association of the antigenic protein with the ribosome.

In vitro translation. The translation of globin $\mathrm{mRNA}$, expressed as the amount of protein synthesized in $1 \mathrm{~h}$, was unaffected by the addition of $9 \mu \mathrm{g}$ of normal human IgG in water in the experiment shown in Table II, and was taken as baseline. In other experiments, some nonspecific inhibition (up to 20-30\%) may be seen, despite the presence of ribonuclease inhibitor. However, IgG containing antibody to histidyl-tRNA synthetase (anti-Jo-1) did inhibit translation to a considerable degree (62\%). Increasing the amount of anti-Jo-1 IgG added by threefold increased the inhibition (to $84 \%$ over normal IgG). Addition of antibody to threonyl-tRNA synthetase (anti-PL7), from the same sample shown in Fig. 2, did not inhibit translation to a significant extent. This was surprising since this anti-PL-7 serum (and all others tested to date [22, 28]) efficiently inhibited threonyl-tRNA synthetase activity, and threonine is present in rabbit globin (31). IgG isolated from a serum with antibody to $\mathrm{Mi}-2$, a DM associated nuclear antigen (8), also did not inhibit translation in the experiment shown. On the other hand, there was dramatic inhibition of translation by IgG from patient K.J., with a $98 \%$ decrease in amount of product formed (99\% with $27 \mu \mathrm{g})$. The stronger inhibition found with $\mathrm{KJ}$ antibody compared to Jo-1 antibody was consistent and reproducible. BT IgG also inhibited strongly; $96.4 \%$ with addition of $18 \mu \mathrm{g} \mathrm{IgG,} 92.5 \%$ with $9 \mu \mathrm{g}$. (These determinations were made in a separate experiment and were not included in the table.) Despite the lower titer of anti-KJ in BT serum, inhibition still exceeded that of anti-Jo-1.

Further studies were done to confirm that the inhibition was due to the anti-KJ antibody in the DEAE-purified IgG

Table II. In Vitro Translation after Direct Addition of Purified IgG to Reticulocyte Lysate before Addition of $m R N A$

\begin{tabular}{lrrrrr}
\hline \multicolumn{1}{c}{ Sample } & 9 $\mu$ : & \multicolumn{1}{c}{ CPM } & \% INHIB & $27 \mu$ g: CPM & \% INHIB \\
\hline Normal IgG & 138,951 & - & 108,109 & - \\
Jo-1 IgG & 52,246 & 62 & 16,908 & 84 \\
PL-7 IgG & 134,316 & 0 & 121,154 & 0 \\
Mi-2 IgG & 161,990 & 0 & 117,379 & 0 \\
KJ IgG & 2,376 & 98 & 1,161 & 99 \\
\hline
\end{tabular}

Each sample was tested after addition of either $9 \mu \mathrm{g}$ or $27 \mu \mathrm{g}$ of IgG. Jo-1, PL-7 and Mi-2 samples represent IgG purified from sera containing those antibodies. CPM, counts per minute in a 5- $\mu$ l aliquot of the reaction mixture after $1 \mathrm{~h}$ of reaction. \% INHIB, \% inhibition of the CPM present after incubation with the respective amount of normal IgG. CPM when no IgG was added was 137,085 . BT serum, which was tested in a different run and was therefore not included in the table, inhibited $92 \%$ at $9 \mu \mathrm{g} \mathrm{IgG}$ added. preparations of $\mathrm{KJ}$ and BT sera. First, the IgG from the two serum samples was purified using protein-A Sepharose affinity chromatography. $\mathrm{KJ}$ IgG continued to inhibit strongly $(98.3 \%$ at $9 \mu \mathrm{g})$ as did BT IgG $(67.3 \%)$ compared to normal IgG. Thus, inhibition of in vitro translation by $\mathrm{KJ}$ and $\mathrm{BT} \mathrm{IgG}$ was independent of the method of purification of the IgG. This inhibitory activity of the $\mathrm{KJ}$ IgG preparation could also be absorbed out of the preparation by protein A-Sepharose. While normal IgG inhibited $0.8 \%$ and $\mathrm{KJ}$ IgG inhibited $94.7 \%$ initially, after absorption with protein A-Sepharose (as described in Methods), the remainder of the preparation formerly containing normal IgG inhibited $0 \%$ while that which formerly contained the KJ IgG inhibited $2.8 \%$. Thus, protein A-Sepharose removed the translation-inhibiting factor from the $\mathrm{KJ}$ IgG preparation.

A third line of evidence that the $\mathrm{KJ}$ antibody itself was responsible for the inhibition was obtained by absorption experiments (Table III). The reticulocyte lysate used for translation was pretreated with protein A-Sepharose coated with antibody. Lysate absorbed with Sepharose coated with normal antibody was usually $20-40 \%$ less effective than untreated lysate at translation of mRNA, probably reflecting nonspecific inhibition. The level of translation after incubating the lysate with Sepharose coated with normal antibody was used as base-

Table III. Inhibition of In Vitro Translation by Absorption

\begin{tabular}{lcrcr}
\hline Sample & INCUB & CPM & \% INHIB & Change \\
\hline No IgG & - & 44,356 & - & - \\
Normal 1 & B & 45,720 & 0 & - \\
Normal 2 & B & 66,757 & 0 & - \\
Normal 3 & B & 50,401 & 0 & - \\
Anti-Jo-1 & B & 8,695 & 80.4 & - \\
KJ (1/4) & B & 14,174 & 68.0 & - \\
BT & B & 2,925 & 93.4 & - \\
Normal 1 & H & 44,285 & 0.2 & +0.2 \\
Normal 2 & H & 32,718 & 26.2 & +26.2 \\
Normal 3 & H & 29,315 & 33.9 & +33.9 \\
Anti-Jo-1 & H & 16,808 & 62.1 & -18.3 \\
KJ (1/4) & H & 43,578 & 1.8 & -66.2 \\
BT & H & 20,401 & 54.0 & -39.4 \\
& & & &
\end{tabular}

IgG purified from test serum was used to coat protein A-Sepharose. After washing, the Sepharose was incubated for $2 \mathrm{~h}$ either with HeLa extract $(H)$ or with HeLa extract buffer $(B)$. The Sepharose was then incubated with reticulocyte lysate. The Sepharose was then sedimented, and the lysate removed for use in in vitro translation as described in Methods. Sample, IgG source used for incubation of Sepharose beads. Samples were IgG purified from three sera from normal subjects, IgG containing anti-Jo-1, and $\mathrm{KJ}$ (coated at $1 / 4$ of the concentration of the other IgG samples tested, $250 \mu \mathrm{g}$ vs. $1 \mathrm{mg}$ ) and BT IgG. INCUB, material used for first incubation of antibody coated Sepharose. CPM, average of duplicate translation runs using lysate absorbed with Sepharose coated with the sample indicated (counts per minute in a 5- $\mu$ l aliquot). \% Inhib, percent drop in CPM when the lysate was absorbed with the Sepharose coated with the sample as compared to coating with no IgG. Change, Difference in \% inhibition that resulted from incubation with HeLa extract as compared to incubation with buffer. $(-)$ indicates that there was less inhibition when the beads were incubated with HeLa extract, and $(+)$ indicates that there was more inhibition after incubation with $\mathrm{HeLa}$ extract. 
line. As shown in Table III, both $\mathrm{KJ}$ and BT strongly inhibit by this method. Sepharose coated with anti-Jo-1 also inhibited translation as expected, with anti-KJ having a greater effect per milligram added in most experiments. For example, in one typical experiment (not shown), anti-Jo-1 coated beads inhibited $20 \%$, while anti-KJ coated beads inhibited $81 \%$. In these experiments, the $\mathrm{KJ}$ IgG sample does not come in contact with the mRNA, yet still inhibits translation, indicating that the effect was on the lysate itself.

If the factor in $\mathrm{KJ}$ serum responsible for inactivating the lysate was in fact the antibody, it should be blocked by antigen. This was confirmed by incubating the antibody-coated protein A-Sepharose with HeLa extract before using it to absorb the lysate. As shown in Table III, when KJ-coated Sepharose was incubated with HeLa extract, the antibody was blocked and the absorption did not inactivate the reticulocyte lysate $(1.8 \%$ inhibition), but Sepharose beads incubated with buffer alone were still effective (68\% inhibition). Sepharose coated with BT IgG (in fourfold higher amount) was highly active at inhibiting the lysate $(93.4 \%)$, but this effect was partially blocked after incubation with $\mathrm{HeLa}$ extract (54\% inhibition). A similar effect of incubation with HeLa extract was seen using an antiJo-1 IgG, but no effect or an opposite effect of this step was seen with Sepharose coated with normal IgG (Table III).

Testing isolated ribosomes for $K J$. The findings that anti$\mathrm{KJ}$ reacted with a cytoplasmic antigen, inhibited translation, did not inhibit the synthetases, and partially immunoprecipitated the small ribosomal RNAs suggested that $\mathrm{KJ}$ antigen could be a ribosomal protein. To investigate this, isolated ribosomes were tested for the presence of the $\mathrm{KJ}$ antigen by a fluorescence inhibition test (Table IV). The ribosomes (or control preparations) were incubated with $\mathrm{KJ}$ serum (or other test serum), and the serum was tested by indirect immunofluorescence to determine whether the amount of anti-cytoplasmic activity was decreased. Incubation with isolated ribosomes prepared in $0.5 \mathrm{M} \mathrm{NH}_{4} \mathrm{Cl}$ had no effect on $\mathrm{KJ}$ serum immunofluorescence activity, but incubation with the same amount of isolated ribosomes markedly inhibited antiribosomal P immunofluorescence. On the other hand, incubation with a postribosomal supernatant very efficiently inhibited the fluorescence of $\mathrm{KJ}$ serum, but showed no inhibition of the immunofluorescence of the anti-P sample, indicating that the ribosomes had been removed. Thus, the anticytoplasmic antibody in $\mathrm{KJ}$ serum does not seem to be directed at an integral

Table IV. KJ Antigen Activity of Ribosomes

\begin{tabular}{cccccc}
\hline Sample & Protein & $\begin{array}{c}\text { KJ } \\
\text { activity }\end{array}$ & $\begin{array}{c}\text { Specific activity } \\
\text { for KJ }\end{array}$ & $\begin{array}{c}\text { Ribosomal-P } \\
\text { activity }\end{array}$ & $\begin{array}{c}\text { Specific } \\
\text { activity } \\
\text { for ribo-P }\end{array}$ \\
\hline $\begin{array}{c}\text { Postribosomal } \\
\text { supernatant }\end{array}$ & 15 & 12 & 0.80 & 0 & 0 \\
Ribosomes & 11.5 & $<1$ & 0.087 & $>8$ & $>0.70$ \\
\hline
\end{tabular}

$\mathrm{KJ}$ and P-protein antigen activity was determined by their inhibition of cytoplasmic fluorescence of the respective sera. $45 \mu \mathrm{l}$ of fraction (or its dilution) was added to $5 \mu \mathrm{l}$ of $1 / 100$ dilution of $\mathrm{KJ}$ serum or $1 / 50$ dilution of anti-P, and preincubated before performing fluorescence. The reciprocal of the highest dilution of fraction still showing some inhibition $=$ inhibitory activity per $\mathrm{ml}$. This was divided by the protein concentration $(\mathrm{mg} / \mathrm{ml})$ to give the specific antigen activity $/ \mathrm{mg}$. ribosomal protein. Considering the immunoprecipitation results, $\mathrm{KJ}$ antigen may have some association with the ribosome at low ionic strength, accounting for the immunoprecipitation results (alternatively, there may be a second antibody). None of the buffers or media had any inhibitory activity of their own.

Purification of KJ. After affinity chromatography, the concentrated, dialyzed affinity eluate had $\mathrm{KJ}$ antigen activity, as demonstrated by ELISA using KJ or BT serum. In addition, this material could completely inhibit the $\mathrm{KJ}$ cytoplasmic immunofluorescent pattern, and produced a precipitin line with $\mathrm{KJ}$ serum. The affinity eluate still contained a large number of proteins (see below) despite extensive washing of the affinity column before elution, and it was therefore further purified and analyzed with FPLC, using gel filtration on Superose 12. Fig. 3 shows the elution profile (OD at $280 \mathrm{~nm}$, reflecting total protein), on which is superimposed the ELISA antigenic activity of each fraction for each of four sera; KJ, BT, a normal serum, and à serum with anti-Ro/SSA. Only the late eluting peaks had activity against $\mathrm{KJ}$ that was not seen with normal serum. Antigenic activity against $\mathrm{KJ}$ serum formed a single peak, but antigenic activity against BT serum eluted in two smaller peaks within the $\mathrm{KJ}$ peak, corresponding to the split peak of $\mathrm{OD}_{280}$. Despite the presence of anti-Ro/SSA in $\mathrm{KJ}$ serum, there was no evidence of Ro/SSA antigenic activity in any of the gel filtration fractions, nor in the whole affinity eluate. Low level background activity against all sera tested corresponded to the other $\mathrm{OD}_{280}$ peaks, indicating that no specific antigen activity was present in them. Pooled active fractions from gel filtration were used for analysis on PAGE.

Analysis by PAGE. Fig. $4 A$ reveals that a number of polypeptides were present in the affinity eluate (lane 2$)$. The strongest band present in the whole eluate on PAGE (seen in Fig. 4 $A$ and in all preparations examined) is $\sim 80-85 \mathrm{kD}$. The FPLC fractions containing this material were not immunologi-

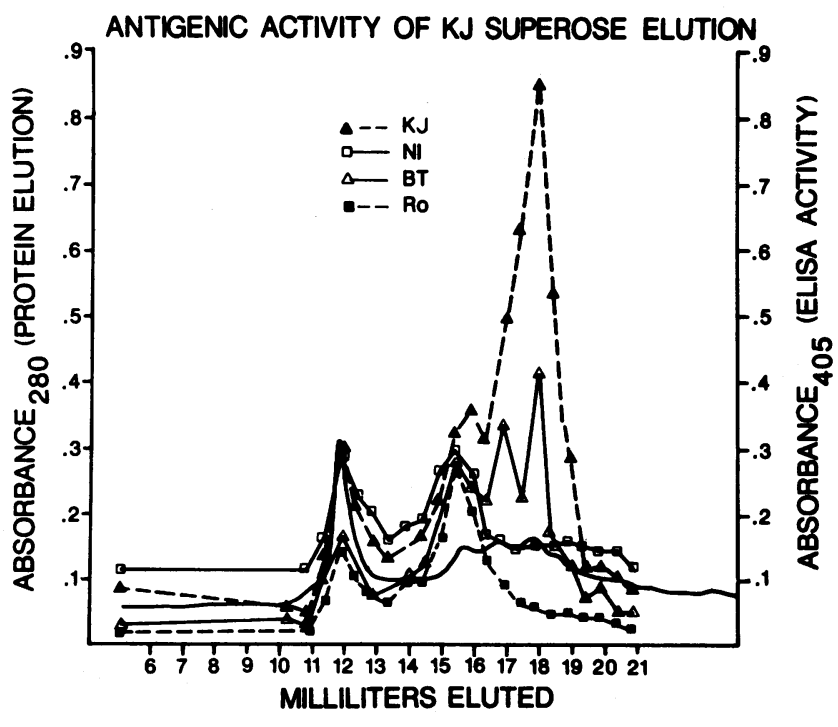

Figure 3. Gel filtration chromatography of $\mathrm{KJ}$ affinity column eluate on Superose 12. Protein is detected by absorbance at $280 \mathrm{~nm}$. ELISA activity of each fraction (using $10 \mu$ l of each fraction $+90 \mu 1$ PBS to coat each well) was determined for each of four sera (KJ, normal, BT, and a standard serum for anti-Ro/SSA). Sera were used at $1 / 300$ dilution. 

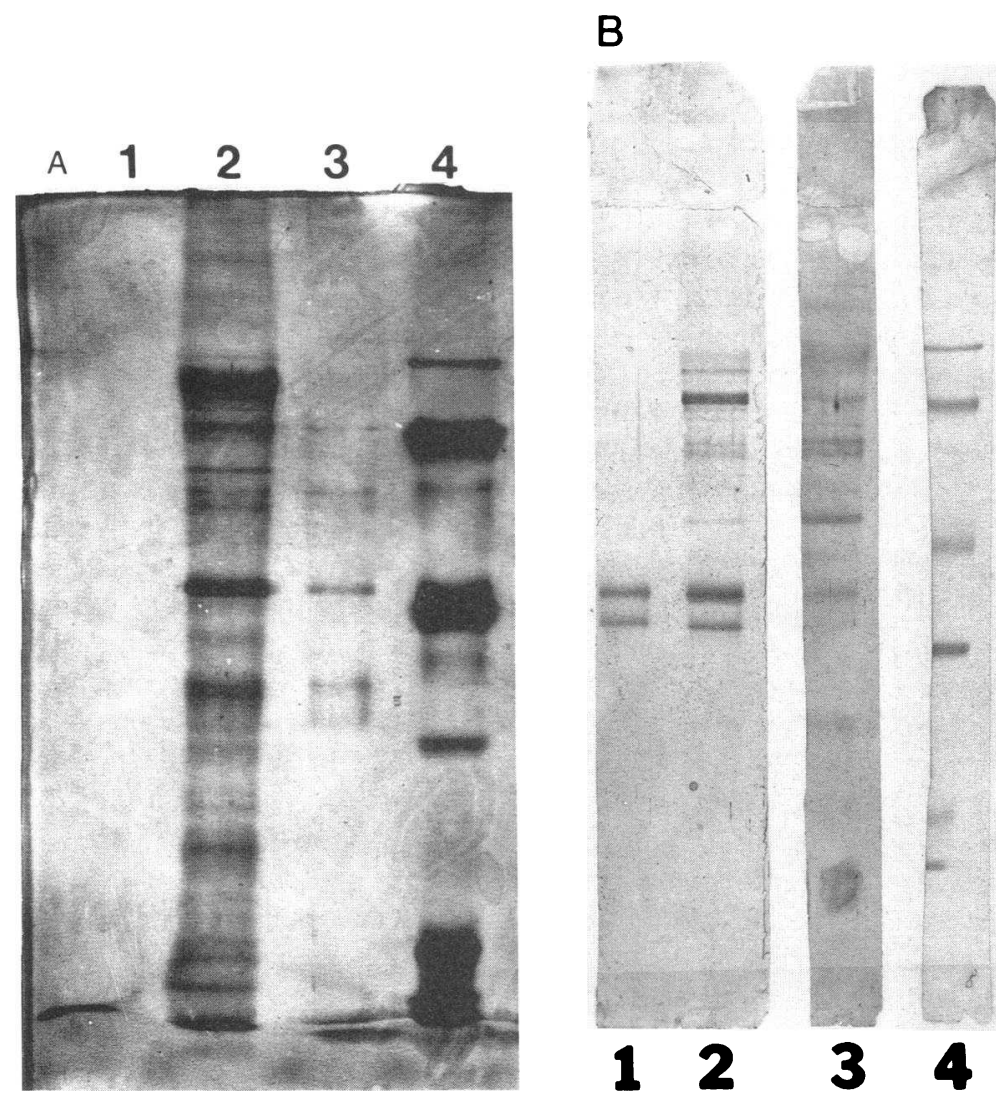

Figure 4. (A) 12\% SDS-PAGE of affinity purified KJ stained with silver stain. Lane 2 contains the whole $\mathrm{KJ}$ affinity eluate. Lane 3 contains the fractions from Superose 12 chromatography that were active against $\mathrm{KJ}$ serum in ELISA (17-18.5 ml), pooled and concentrated. Lane 4 contains molecular weight markers $(94,67,43,30,20.1$, and $14.4 \mathrm{kD}$ ). (B) Western blot of polyacrylamide gel run with gel in A. Lanes 1 and 2 were developed with $\mathrm{KJ}$ serum, 1/100. Lane 3 was developed with normal serum, $1 / 100$. Lane 4 contained molecular weight markers and was developed with amido black. Whole $\mathrm{KJ}$ affinity eluate was run in lanes 2 and 3 (as in lane 2 in $A$ ), while pooled active fractions (as in lane 3 in $A$ ) were run in lane 1 . Bands at 32, 36, and 68-70 kD were stained more heavily by $\mathrm{KJ}$ than normal serum, but only the fractions with the 32- and $36-\mathrm{kD}$ bands were active in ELISA.

cally active in ELISA, and the pooled active fractions did not contain this band (lane 3 ). In addition to this band, the whole eluate contained prominent bands at $\sim 24 \mathrm{kD}, 30-35 \mathrm{kD}, 45$ $\mathrm{kD}$, a doublet at $55-60 \mathrm{kD}$, and a doublet at $68-70 \mathrm{kD}$, as well as other weaker bands. A substantial further purification was evident in comparing the whole eluate to the pooled active fractions from Superose 12 chromatography (lane 3). The latter contained two discrete bands, one ranging between 30 and $33 \mathrm{kD}$, and the other between 33 and $36 \mathrm{kD}$, in addition to fainter bands at $45 \mathrm{kD}, 70 \mathrm{kD}$, and a doublet at 55-60 kD. After transfer to nitrocellulose (Fig. $4 \mathrm{~B}$ ), there was prominent staining with $\mathrm{KJ}$ serum of the bands at molecular weights of 30 $\mathrm{kD}$ and $34 \mathrm{kD}$, in both the whole affinity eluate and the active Superose fractions. Although faint background staining is seen with normal serum in the experiment shown, the 30- and 34-kD bands stain with $\mathrm{KJ}$ serum strongly and consistently in all runs, and usually show little background. Also evident in Fig. $4 B$ is staining of the $70-\mathrm{kD}$ band. There is no corresponding FPLC fraction with $\mathrm{KJ}$ or Ro/SSA ELISA activity eluting from the Superose column in this molecular weight range. This band is not consistently demonstrable in blots of whole $\mathrm{KJ}$ affinity eluates, possibly reflecting proteolytic breakdown. The Western blot confirms that the $80-85-\mathrm{kD}$ band does not contain antigenic activity. The $24-\mathrm{kD}, 45-\mathrm{kD}$, and 55-60-kD bands also appear to lack antigenic activity when compared to normal.

\section{Discussion}

We report two patients with ILD and PM, who have an autoantibody directed at a cytoplasmic antigen that is involved in the process of translation of mRNA, the central process in protein synthesis. This same clinical syndrome of lung disease and PM also affects many patients with antibodies to amino-
acyl-tRNA synthetases. Since the synthetases also play a necessary role in translation, there is a functional relationship between the antigens that have been associated with this syndrome: His-, Thr-, and Ala- tRNA synthetases, and KJ.

Substantial evidence was presented that $\mathrm{KJ}$ antigen is not a synthetase. Lack of inhibition of synthetase activity is strong evidence in favor of this conclusion. We have found inhibition of histidyl-tRNA synthetase activity by all sera with anti-Jo-1 (detectable by ID) that we have tested, now including sera from over 30 patients, and by all sera with threonyl-tRNA synthetase. In general, this method could fail to detect an antibody that combined with the antigenic enzyme without inactivating it, or an antibody reacting exclusively with one form of the enzyme (for example, the mitochondrial form), allowing the reaction to be catalyzed by others. However, the results of the translation inhibition studies indicate that anti-KJ can completely abolish the function of $\mathrm{KJ}$ antigen. Studies with anti-Jo-1 and anti-PL-7 indicate that translation inhibition is a less sensitive method of detecting functional inhibition of synthetases than is aminoacylation inhibition, possibly because the concentration of synthetase can be specifically controlled in the latter. There is also supportive data provided by immunoprecipitation. All recognized autoantibodies to synthetases have precipitated the cognate tRNA for the respective amino acid, while KJ did not precipitate tRNA. Failure to precipitate tRNA does not in itself rule out the presence of an antisynthetase, but combined with the enzyme inhibition data, there is a strong case against the $\mathrm{KJ}$ antigen being a synthetase.

The evidence presented also indicates that the $\mathrm{KJ}$ antigen plays an important role in protein synthesis, since in vitro translation of globin mRNA is prevented by binding of antibody to $\mathrm{KJ}$ antigen, or removal of $\mathrm{KJ}$ antigen from the reticulocyte lysate. It is unlikely that complicating factors such as 
ribonucleases in the IgG preparation accounted for this effect. Evidence for this included: $(a)$ the effect was independent of the method of IgG purification; $(b)$ it could be produced either by absorption of the lysate or by direct addition of antibody; (c) the effect of antibody could be blocked by extract containing the antigen; and $(d)$ IgG from both sera containing the antibody had this effect, but not with IgG from myositis sera containing nontranslation related antibodies or from normal sera. The level of inhibition of translation that was observed with anti-KJ (from either KJ or BT) was stronger than was generally seen with antisynthetases. Inhibition with high titer anti-Jo-1 was less complete, even when threefold more antibody was added, and no inhibition at all was seen with antiPL-7 sera. This may be related to the relative amounts of the antigens and antibodies, or it might reflect an aspect of the respective functions of the antigens, implying that the role of the $\mathrm{KJ}$ antigen in translation is more direct. Mathews et al. (32) also found that anti-PL-7 serum did not inhibit translation, while Elkon et al. (39) found that antibody to the ribosomal $\mathbf{P}$ proteins, which are more directly involved in formation of the polypeptide chain, strongly inhibited translation.

Although anti-KJ antibody can clearly disturb protein synthesis in vitro, it is unlikely that this occurs in vivo, or that inhibition of protein synthesis is involved in disease pathogenesis, since the antibody would not ordinarily enter the living cell. Analysis of the effects of $\mathrm{KJ}$ antibody on in vitro protein synthesis was useful, however, to study the function of the $\mathrm{KJ}$ antigen, and should prove to be useful for the study of other anticytoplasmic antibodies. Others have reported inhibition of in vitro translation by autoantibodies $(32,39,40)$. Reedy et al. (40) reported preliminary results showing some inhibition of translation by anti-Jo-1 sera. Our study confirms that antibody to Jo-1 interferes with translation of globin mRNA, presumably by preventing the formation of charged tRNA ${ }^{\text {his }}$. Reedy et al. also found evidence of partial inhibition of translation by a number of diluted myositis sera without anti-Jo-1, and enhancement of translation by others, but they did not study isolated IgG, they did not analyze the individual specificities of the inhibiting antibodies (other than anti-Jo-1), and the effects noted were small compared to those shown here for anti-KJ. Mathews et al. (32) studied the effects of IgG from myositis sera on in vitro translation, and found that anti-Jo-1 IgG inhibited translation. IgG with anti-Fer, another antibody that was found in myositis and that immunoprecipitates tRNA, did not inhibit translation.

Our data clearly show that $\mathrm{KJ}$ antigen is not ribosomal $\mathrm{P}$ antigen. It is possible that $\mathrm{KJ}$ is a different protein with affinity for the ribosome, a possibility supported by the immunoprecipitation results. Most proteins involved in translation, including some synthetases (21), associate at one point or another with the ribosome in the course of performing their function. However, the evidence presented makes it unlikely that $\mathrm{KJ}$ antigen is an integral part of the ribosome. It is still present in extracts after removal of ribosomes by centrifugation, and it is not a part of ribosomes isolated at $0.5 \mathrm{M}$ salt according to immunofluorescence inhibition data. The $\mathrm{KJ}$ precipitin line in Ouchterlony immunodiffusion was nonidentical with that of anti-P, using an extract prepared in $0.15 \mathrm{M}$ salt, suggesting that the two antigens exist on different particles.

Since it does not appear to be a synthetase or an integral ribosomal protein, but does inhibit translation, $\mathrm{KJ}$ antigen is most likely to be a translation factor. The inhibition results that were observed could have been produced by inhibition of crucial initiation or elongation factors. Thus far, we have been unable to identify $\mathrm{KJ}$ antigen as a described translation factor. Further analysis of its structure may be helpful in this regard. The FPLC, ELISA, and Western blot data indicate that the most strongly antigenic polypeptides are of $\sim 30-32 \mathrm{kD}$ and 34-36 kD, but these may be breakdown products, possibly of the $70-\mathrm{kD}$ antigenic band seen in some whole affinity eluates. These antigenic polypeptides may be present in vivo in a complex with the $80-85-\mathrm{kD}$ band, and possibly others.

The reason for the split peak of ELISA activity seen on analysis of gel filtration fractions with BT serum is unclear. Both parts of the split peak of BT fall within the $\mathrm{KJ}$ peak, and it is possible that the apparent difference in reactivity is an effect of the relative titers. Since BT and KJ sera have an identical precipitin line in Ouchterlony, they must react with the same complex, although it is conceivable that they are reacting with different portions of it. It is possible, because of the fine resolution of the FPLC, that the two peaks represent the 30 - and $34-\mathrm{kD}$ bands. There may be additional reactivity not evident in Western blot because of denaturation of the antigen. The other band seen in active fractions, of $45 \mathrm{kD}$, was present in other, inactive fractions, and was not stained on blot, but the possibility that it is involved must be kept in mind.

The question of whether the $\mathrm{KJ}$ antigen is related to tRNA is an important one, as discussed below. Our data indicate that KJ serum does not immunoprecipitate tRNA, so that the antigen is not itself tRNA, nor does it form stable complexes with tRNA under the conditions of the immunoprecipitation. Other autoantibodies to nucleoprotein complexes tend to immunoprecipitate the nucleic acid present. Establishing the molecular identity of the antigen will help to settle this question. It is unlikely, however, that the lack of precipitation of tRNA by $\mathrm{KJ}$ serum was due to low sensitivity of the method. This method of immunoprecipitation, involving silver stain of immunoprecipitates from extracts that had not been radioactively labeled, was shown by Forman et al. (29) to be almost as sensitive on a qualitative basis as ${ }^{32} \mathrm{P}$ immunoprecipitation (it can identify almost all positive sera), and $\mathrm{KJ}$ serum had a high titer of anti-KJ. Anti-Jo-1 and anti-PL-7 were easily detected in other sera, as was the weak anti-Ro/SSA in $\mathrm{KJ}$ serum itself. It is also unlikely that the lack of precipitation of tRNA was due to a lack of $\mathrm{KJ}$ antigen in $\mathrm{HeLa}$ extract. $\mathrm{KJ}$ antigen was present in HEp-2 cells (another human line) by fluorescence, and proteins necessary for translation should be required by all active cells. While $\mathrm{KJ}$ serum did not precipitate tRNA, BT serum did precipitate a faint band of tRNA. This was most likely due to a coexistent antibody, since the ELISA data and the immunofluorescence data indicate that BT contains a lower titer of anti-KJ than does $\mathrm{KJ}$ serum, and one would have expected to see it with $\mathrm{KJ}$ serum also if the anti-KJ were responsible.

Anti-KJ was found in only two patients, and it is difficult to draw conclusions about clinical associations with such a small number. However, of the entire group of antisynthetase negative myositis patients, patients with the myositis/lung disease syndrome (PM/ILD) in association with Raynaud's phenomenon are not common, particularly in the absence of scleroderma. An association has also been reported of lung disease with anti-PM-Scl $(7,9,41)$ and anti-nRNP $(9,42)$ in the setting of overlap syndromes, but these antibodies also were not present here. Although B.T. did develop manifesta- 
tions of scleroderma, her disease began as PM with ILD, and remained so for 2 yr. (We do not know when anti-KJ developed in B.T.) Thus, the association of anti-KJ with two patients with this syndrome is striking. The presence of anti-Ro/ SSA in KJ serum is interesting, and we have observed it also in association with anti-synthetases.

Patients with the PM/ILD syndrome may represent a separate subgroup within adult PM (9), that is a more uniform group than adult PM patients as a whole. They share an association with antibodies to cytoplasmic antigens that have the functional relationship described here, in that they are all involved in translation. Antibodies to individual synthetases do not cross-react with other synthetases (or with $\mathrm{KJ}$ ), indicating that it is not a shared epitope that is targeted, and it may be an aspect of their related function that causes these otherwise distinct proteins to become antigenic to patients with the same syndrome. It has been suggested that this aspect is a relationship to tRNA (22). The Mas and Fer specificities, both described in myositis, are both tRNA related antigens but they do not appear to be synthetases. KJ, however, does not appear to be a synthetase, nor is there evidence of association with tRNA (although as discussed above, our negative evidence cannot rule this out). This may indicate that the function in translation is related to the development of immunogenicity. It is interesting in this regard that the signal recognition particle (SRP) has been repeatedly shown to be an antigen in polymyositis patients (43-46). The SRP targets secretory proteins into the endoplasmic reticulum, recognizing them as they are being translated, and can have effects on their translation. Anti-SRP is associated with PM, but not with a high frequency of ILD (46). Understanding the reason for the focus of these antibodies on cytoplasmic antigens and translation may provide insights into the etiologic and pathogenetic mechanisms of PM.

It has been suggested previously (4) that the reason antibodies to synthetases develop in myositis patients is that the synthetases can specifically interact with the RNA of certain viruses. There is some experimental support for such interactions. It has been reported that the RNA of two picornaviruses (Mengo and encephalomyocarditis) can accept a specific amino acid (histidine and serine, respectively) as if there were a tRNA-like structure as part of their genome $(47,48)$. An autoimmune response against the synthetase may result if a stable complex of synthetase and virus (such as that formed between the synthetase and its natural tRNA substrate) is presented to the immune system as a foreign antigen (4); if the complementarity of virus and synthetase leads to cross-reaction of antiidiotypic antibodies to the antiviral antibodies with the synthetase (49); or possibly by other mechanisms. There is a considerable amount of independent evidence (50-54) for a viral etiology for at least some forms of PM (particularly for Coxsackie, also a picornavirus), and thus this hypothesis has been especially attractive. Picornaviruses are small RNA viruses whose RNA serves directly as a positive strand of messenger RNA. An early step in picornavirus infection of a cell is the shutdown of translation of host mRNA (55). Shortly thereafter, the host cell protein synthesizing machinery begins to efficiently translate viral mRNA, but it is still unable to translate host mRNA. There may be differences in the mechanism by which different picornaviruses exert these effects. Manipulation of this intricate mechanism in this precise manner by the virus would likely involve specific interactions of viral RNA and protein with host RNA and protein, but would not seem to require interaction with nuclear proteins or DNA. Thus, if viral/host interactions were the basis for selection of particular proteins to be antigens, and if picornaviruses (or viruses with a similar mechanism) were responsible for the PM/ILD syndrome, it would not be surprising to find antibodies to tRNA or translation-related proteins in this syndrome.

In summary, two patients with polymyositis, interstitial lung disease, and Raynaud's phenomenon, were found to have an autoantibody, labeled anti-KJ, that can strongly inhibit translation of mRNA. KJ antigen did not appear to be either an integral ribosomal protein, nor a synthetase, and it may be a translation factor. The functional relationship of $\mathrm{KJ}$ antigen and the synthetase antigens, and similar clinical presentation of the patients, may relate to similar viral triggers for the generation of the antibodies and the clinical syndrome.

\section{Acknowledgments}

The authors wish to thank Dr. Paul Agris for helpful discussions concerning the translation assay; Dr. E. M. Hampton for assistance with the presentation of the data; Elizabeth Chamberlain and Keith Conaway for excellent technical assistance; and Bonnie Wilds for assistance in the preparation of the manuscript.

Supported by Veterans Administration Medical Research Funds from the Veterans Administration Medical Center, Oklahoma City, OK, and NIH grant AM-32214-03, and aided by a grant from the Arthritis Foundation and the Texas Gulf Chapter of the Arthritis Foundation. Dr. Targoff is a Research Associate of the Veterans Administration.

\section{References}

1. Mastaglia, F. L., and V. J. Ojeda. 1985. Inflammatory myopathies. Part 1 \& 2. Ann. Neurol. 17:216-227, 317-323.

2. Reichlin, M., and F. C. Arnett. 1984. Multiplicity of antibodies in myositis sera. Arthritis Rheum. 27:1150-1156.

3. Targoff, I. N. 1988. Laboratory manifestations of polymyositis/ dermatomyositis. Clin. Dermatol. 6:76-92.

4. Mathews, M. B., and R. M. Bernstein. 1983. Myositis autoantibody inhibits histidyl-tRNA synthetase. A model for autoimmunity. Nature (Lond.). 304:177-179.

5. Yang, D. C. H., C. V. Dang, and F. C. Arnett. 1984. Rat liver histidyl-tRNA synthetase. Purification and inhibition by the myositisspecific anti-Jo-1 autoantibody. Biochem. Biophys. Res. Commun. 120:15-21.

6. Nishikai, M., and M. Reichlin. 1980. Heterogeneity of precipitating antibodies in polymyositis. Characterization of the Jo-1 antibody system. Arthritis Rheum. 23:881-888.

7. Reichlin, M., P. J. Maddison, I. N. Targoff, T. Bunch, F. C. Arnett, G. Sharp, E. Treadwell, and E. M. Tan. 1984. Antibodies to a nuclear/nucleolar antigen in patients with polymyositis-overlap syndrome. J. Clin. Immunol. 4:40-44.

8. Targoff, I. N., and M. Reichlin. 1985. The association between Mi-2 antibodies and dermatomyositis. Arthritis Rheum. 28:796-803.

9. Bernstein, R. M., and M. B. Mathews. 1985. Jo-1 and other myositis autoantibodies. In Rheumatology-85, Excerpta Medica Int. Congr. Ser. P. M. Brooks and J. R. York, editors. Elsevier Science Publishers, New York. 273-278.

10. Reichlin, M. 1985. Antinuclear antibodies. In Textbook of Rheumatology. W. N. Kelly, E. Harris, S. Ruddy, and C. B. Sledge, editors. W. B. Saunders Co., Philadelphia. 690-707.

11. Bohan, A., and J. B. Peter. 1975. Polymyositis and dermatomyositis. Parts 1 and 2. N. Engl. J. Med. 292:344-347, 403-407.

12. Bohan, A., J. B. Peter, R. L. Bowman, and C. M. Pearson. 1977. A computer-assisted analysis of 153 patients with polymyositis and dermatomyositis. Medicine (Baltimore). 56:255-286.

13. Arnett, F. C., T. J. Hirsch, W. B. Bias, M. Nishikai, and M. 
Reichlin. 1981. The Jo-1 antibody system in myositis: relationships to clinical features and HLA. J. Rheumatol. 8:925-930.

14. Targoff, I. N., and M. Reichlin. 1987. Measurement of antibody to Jo- 1 by ELISA and comparison to enzyme inhibitory activity. J. Immunol. 138:2874-2882.

15. Yoshida, S., M. Akizuki, T. Mimori, H. Yamagata, S. Inada, and $\mathrm{M}$. Homma. 1983. The precipitating antibody to an acidic nuclear protein antigen, the Jo-1, in connective tissue disease. A marker for a subset of polymyositis with interstitial pulmonary fibrosis. Arthritis Rheum. 26:604-611.

16. Walker, E. J., K. E. Tymms, J. Webb, and P. D. Jeffrey. 1987. Improved detection of anti-Jo-1 antibody, a marker for myositis, using purified histidyl-tRNA synthetase. J. Immunol. Methods. 96:149-156.

17. Biswas, T., F. W. Miller, Y. Takagaki, and P. H. Plotz. 1987. An enzyme-linked immunosorbent assay for the detection and quantitation of anti-Jo-1 antibody in human serum. J. Immunol. Methods. 98:243-248.

18. Bernstein, R. M., S. H. Morgan, J. Chapman, C. C. Bunn, M. B. Mathews, M. Turner-Warwick, and G. R. V. Hughes. 1984. Anti-Jo-1 antibody: a marker for myositis with interstitial lung disease. Br. Med. J. 289:151-152.

19. Hochberg, M. C., D. Feldman, M. B. Stevens, F. C. Arnett, and M. Reichlin. 1984. Antibody to Jo-1 in polymyositis/dermatomyositis: Association with interstitial pulmonary disease. J. Rheumatol. 11:663-665.

20. Wasicek, C. A., M. Reichlin, M. Montes, and G. Raghu. 1984. Polymyositis and interstitial lung disease in a patient with anti-Jo-1 prototype. Am. J. Med. 76:538-544.

21. Dang, C. V., and C. V. Dang. 1986. Higher eukaryotic aminoacyl-tRNA in physiologic and pathologic states. Mol. Cell Biochem. 71:107-120.

22. Mathews, M. B., M. Reichlin, G. R. V. Hughes, and R. M. Bernstein. 1984. Anti-threonyl-tRNA synthetase, a second myositisrelated autoantibody. J. Exp. Med. 160:420-434.

23. Okada, N., R. Mukai, F. Harada, T. Kabashima, Y. Nakao, K. Yamane, Y. Ohshima, K. Sakamoto, M. Itoh, H. Kashiwagi, and H. Hamıaguchi. 1984. Isolation of a novel antibody which precipitates ribonucleoprotein complex containing threonine tRNA from a patient with polymyositis. Eur. J. Biochem. 139:425-429.

24. Bunn, C. C., R. M. Bernstein, and M. B. Mathews. 1986. Autoantibodies against alanyl-tRNA synthetase and tRNA ${ }^{\text {ala }}$ coexist and are associated with myositis. J. Exp. Med. 163:1281-1291.

25. Targoff, I. N. 1988. New anti-synthetases in polymyositis. $A r-$ thritis Rheum. 31:S13. (Abstr.)

26. Elkon, K. B., A. P. Parnassa, and C. L. Foster. 1985. Lupus autoantibodies target ribosomal P proteins. J. Exp. Med. 162:459-471.

27. Pearson, R. L., C. W. Hancher, J. F. Weiss, D. W. Holladay, and A. D. Kelmers. 1973. Preparation of crude transfer RNA and chromatographic transfer RNAs from calf liver. Biochem. Biophys. Acta. 294:236-249.

28. Targoff, I. N., F. C. Arnett, and M. Reichlin. 1988. Antibody to threonyl-transfer RNA synthetase in myositis sera. Arthritis Rheum. 31:515-524.

29. Forman, M. S., M. Nakamura, T. Mimori, C. Gelpi, and J. A. Hardin. 1985. Detection of antibodies to small nuclear ribonucleoproteins and small cytoplasmic ribonucleoproteins using unlabelled cell extracts. Arthritis Rheum. 28:1356-1361.

30. Jackson, R. J., and T. Hunt. 1983. Preparation and use of nuclease treated rabbit reticulocyte lysates for the translation of eukaryotic messenger RNA. Methods Enzymol. 96:50-74.

31. Croft, L. R. 1980. Handbook of protein sequence analysis. John Wiley and Sons, Chichester. pp. 247-258.

32. Mathews, M. B., C. C. Bunn, and R. M. Bernstein. 1985 Autoantibodies to Jo- 1 and other tRNA-related antigens in myositis. In Rheumatology-85, Excerpta Medica Int. Congr. Ser. P. M. Brooks and J. R. York, editors. Elsevier Science Publishers, New York. 189-192.

33. Woodward, W. R., J. L. Ivey, and E. Herbert. 1974. Protein synthesis with rabbit reticulocyte preparations. Methods Enzymol. 30:724-731.

34. Yamagata, H., J. B. Harley, and M. Reichlin. 1984. Molecular properties of the Ro/SSA antigen and ELISA for quantitation of antibody. J. Clin. Invest. 74:625-633.

35. Laemmli, U. K. 1970. Cleavage of structural proteins during the assembly of the head of bacteriophage T4. Nature (Lond.). 227:680-685.

36. Towbin, H., T. Staehelin, and J. Gordon. 1979. Electrophoretic transfer of proteins from polyacrylamide gels to nitrocellulose sheets: procedure and some applications. Proc. Natl. Acad. Sci. USA. 76:4350-4354.

37. Moldave, K., and I. Sadnik. 1979. Preparation of derived and native ribosomal subunits from rat liver. Methods. Enzymol. 59:402410.

38. Bradford, M. M. 1976. A rapid and sensitive method for the quantitation of microgram quantities of protein utilizing the principle of protein-dye binding. Anal. Biochem. 72:248-254.

39. Elkon, K. B., S. Skelly, A. Parnassa, H. Weissbach, and N. Brot. 1986. Lupus anti-P serum inhibits protein synthesis in vitro. Arthritis. Rheum. 29:S102.

40. Reedy, D. B., A. M. Boak, S. H. Zwillich, and P. F. Agris. 1984. Evaluation of specific autoimmune antibodies utilizing in vitro translation. Arthritis Rheum. 27:S29. (Abstr.)

41. Treadwell, E. L., M. A. Alspaugh, J. F. Wolfe, and G. C. Sharp. 1984. Clinical relevance of PM-1 antibody and physiochemical characterization of PM-1 antigen. J. Rheumatol. 11:658-662.

42. Venables, P. J. W., P. A. Mumford, and R. N. Maini. 1981. Antibodies to nuclear antigens in polymyositis: Relationship to autoimmune "overlap syndromes" and carcinoma. Ann. Rheum. Dis. 40:271-223.

43. Okada, N., T. Mimori, R. Mukai, H. Kashiwagi, and J. A. Hardin. 1987. Characterization of human autoantibodies that selectively precipitate the 7SL RNA component of the signal recognition particle. J. Immunol. 138:3219-3223.

44. Reeves, W. H., S. K. Nigam, and G. Blobel. 1986. Human autoantibodies reactive with the signal-recognition particle. Proc. Natl. Acad. Sci. USA. 83:9507-9511.

45. Andrews, G. A., and R. Kole. 1987. Alu RNA transcribed in vitro binds the $68-\mathrm{kDa}$ subunit of the signal recognition particle. $J$. Biol. Chem. 262:2908-2912.

46. Targoff, I. N., A. E. Johnson, and F. W. Miller. 1988. Polymyositis and antibody to signal recognition particle. Clin. Res. 36:537a. (Abstr.)

47. Haenni, A. L., S. Joshi, and F. Chapeville. 1982. tRNA-like structures in the genomes of RNA viruses. Prog. Nucleic. Acid. Res. 27:85-104.

48. Salomon, R., and U. Z. Littauer. 1974. Enzymatic acylation of histidine to mengovirus RNA. Nature (Lond.). 249:32-34.

49. Plotz, P. H. 1983. Autoantibodies are anti-idiotype antibodies to antiviral antibodies. Lancet. ii:824-826.

50. Pearson, C. M. 1975. Myopathy with viral-like structures (editorial). N. Engl. J. Med. 292:641-642.

51. Denman, A. M. 1984. Aetiology. Clin. Rheum. Dis. 10:9-33.

52. Christensen, M. L., L. M. Pachman, R. Schneiderman, D. C. Patel, and J. M. Friedman. 1986. Prevalence of Coxsackie B virus antibodies in patients with juvenile dermatomyositis. Arthritis Rheum. 29:1365-1370.

53. Strongwater, S. L., K. Dorovini-Zis, R. D. Ball, and T. J. Schnitzer. 1984. A murine model of polymyositis induced by Coxsackievirus Bl (Tucson strain). Arthritis Rheum. 27:433-442.

54. Bowles, N. E., V. Dubowitz, C. A. Sewry, and L. C. Archard. 1987. Dermatomyositis, polymyositis, and Coxsackie-B-virus infection. Lancet. i:1004-1007.

55. Ehrenfeld, E. 1984. Picornavirus inhibition of host cell protein synthesis. In Comprehensive Virology: Viral Cytopathology-Cellular Macromolecular Synthesis and Cytocidal Viruses. H. Fraenkel-Conrat and R. R. Wagner, editors. Plenum Publishing Corp., New York. 177-222. 